\title{
Market Profitability Factors Exploration after the Stock Holding Event of Listed Companies Executives-Evidence from China's Stock Market
}

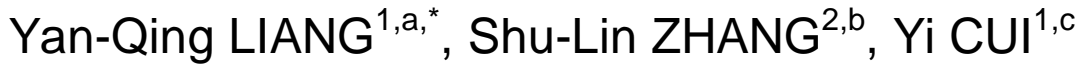 \\ ${ }^{1}$ School of Business Administration, South China University of Technology, Guangzhou, China \\ ${ }^{2}$ School of Mathematics, South China University of Technology, Guangzhou, China \\ ayanqing_liang@126.com, bslzhang@scut.edu.cn, cbmyicui@scut.edu.cn \\ ${ }^{*}$ Corresponding author
}

Keywords: Executives increasing shareholding, Event study, Market reaction, Profitability factor.

\begin{abstract}
There are fewer detailed studies and empirical research on the related profitability factors for executives increase shareholding event of listed companies in China. We find out the market has a significant positive average cumulative abnormal returns after the announcement of listed companies' executive increase shareholding. Multivariate regression model was used to analyze and test the profitability factors which effect the abnormal returns of the executives increase shareholding event. In this paper we find the lower valuation of companies, smaller market capitalization, lower ownership concentration, and lower stock prices volatility before the event are the significant four profitability factors which can help the investors obtain above-average income levels.
\end{abstract}

\section{Introduction}

In the security secondary market of China, equity incentive management measures were carried out to provide the condition for executives' shareholding circulation, and that also improve the value of capital market investment. Because the insider participates in the operating decision-making activities, they have more information advantage than outside investors. Executives can make full use of the advantages of valuation judgment in securities trading, and accurate grasp valuation deviation of opportunity to buy in or cash out. Insiders can select trading opportunities and disclosure timing, so there is a mismatching between the cumulative abnormal returns (CAR) and the risk they take. But the outsider investors often follow executives' trading strategy in a high cost without accurate judgment of the listed companies' intrinsic value and prospects. For now, the investment strategy research about executives increase shareholding mainly concentrated in two aspects. One is to test the executives increasing shareholding events whether give rise to market reaction. Another aspect is to research the motivation of executives increase shareholding and to test whether it is relate to the insider trading. Nevertheless, the research about how to get a higher CAR by studying the factors of the executives increasing shareholding events is very few. And this paper study the abnormal returns factors around executives increasing shareholding events based on disclosed trading data.

\section{Related work and research hypotheses}

Eugene Fama in 1970 put forward the efficient market hypothesis (EMH), based on whether the stock price absorbs different types of information and reflect the stock price. At present, a large number of empirical study shows that our country securities market is a Weak-Form Market Efficiency. The market price can be fully reaction securities history information. Executives as the insiders of the listed companies, who participate in the activities of the companies' business decisions directly, can detect the change of the companies' fundamentals and performance at the earliest. J.Dennert (1991) refers to special information traders that the insider can highly accurate information and receive information acquisition with low costs [1]. And the study of Aussenegg and Ranzi(2008)concluded that because of the insider information superiority about the state of operation, they have obvious excellent performance prediction and short-term market timing ability in the trading [2]. Outside investors make the investment strategy often based on insider trader's behavior. Yang Yang (2013) found that senior executive increased shareholdings event will be interpreted as a positive signal of the capital markets and generate positive 
earnings [3], like "Herd Effect" obviously. Based on the above theory, we make the first hypothesis in this paper.

H1: After the announcement of executives increasing shareholding event, the market have a short-term positive reaction.

However, many public information are often entrained "information noise", Huang Jiacheng and Wang Zebin (2013) found that executives presence profit manipulative behavior in the process of the increased shareholding [4]. Friederich (2002) found the smaller, poorer liquidity of the companies, the more outstanding insider information advantage [5]. So the stock price will get a larger reaction and obtain higher excess returns after the executives increase shareholding. And Claessens (2000) also found that with increasing concentration of ownership, the controlling shareholder have the larger possibility to encroach small shareholders' interest, and declining the value of public companies [6]. Based on the above analysis, we make the second hypothesis in this paper.

$\mathrm{H} 2$ : The smaller market capitalization and lower ownership concentration the companies have, the higher abnormal returns the executives increasing shareholding shows.

Zhu Tufen, Yao Zheng and Li Zhiwen (2011) found that the stock's price exist abnormal volatility increases before the announcement, which means the information disclosure about the executives increase shareholding before the event [7]. So there has a certain reaction both in stock prices and trading volume. The stocks with information disclosure or market reaction before event cannot get a higher returns than those without information disclosure after the event. Leland proposed a rational expectations model and believes that insider trading will increase the average price of the stock, while under normal circumstances the stock price volatility will increase. So purchasing the stocks with information disclosure will received a smaller or even negative return after the event announcement. Based on the above analysis, we make the third hypothesis in this paper.

H3: Before the executives increasing shareholding event announcement, the smaller abnormal volatility the stock price appears, the higher abnormal returns those stock price shows after the announcement.

Fang Tianliang (2010) found that the higher the cumulative abnormal returns can be obtained after the executives increased shareholding was announced [8]. The companies had a lower ratio of the market value of the book. Executives increasing shareholding behavior could be taken as the executives' confidence to companies in the future and the companies was undervalued. A small part of companies use increasing shareholdings to raise the stock price, in order to achieve other refinancing purposes, just like a "show" in the securities market. Based on the above analysis, we make the fourth hypothesis in this paper.

$\mathrm{H} 4$ : If executives increase their shareholding because the value of the companies was undervalued, the market reaction is more obvious after the event announcement.

Lakonishok and Lee (2001) pointed that the company profitability is higher, if the insider buying the stock, respect to those companies which insider selling stock, mainly because that insider have some private information [9]. Yu Haiyun and Wang Zebin(2010) found that the behavior of shareholders increasing shareholding has a significant positive correlation with the earnings growth[10]. In addition, there is a high growth potential and good history performance of the companies, investors are willing to increase shareholdings. Based on the above analysis, we are going to make the last hypothesis in this paper.

H5: The better performance the listed companies had, the more the abnormal returns can be got after the executives increase shareholding event.

\section{Study Design}

\section{Data Description}

The data used in this study is collected from the Wind database and Tinysoft database, and be operated by SPSS Statistics 20 software etc. We selects executives increased shareholding events which occurred in Shanghai and Shenzhen A-share public companies from 2007 January 1 to 2014 September 25. In order to ensure the effectiveness of the sample data, we need to eliminate the abnormal samples which have a great impact on the study, such as financial listed companies, the companies with incomplete data, ST and PT shares, listed less than three months and those with some important incidents in the last three months. If the same companies happen several increased shareholding events in the same day, we combine 
them as one event. After the above operation, 2999 samples have finally been chosen. From January 1, 2007 to December 31, 2013, there are 2735 samples as the train data to build model. From January 1, 2014 to September 25, 2014, there are 264 samples as the test data to verify the extrapolate performance of the model. Observed factors data selected from recent fiscal annual report before the executives increasing shareholding event announcement. As required by CSRC timely disclosure of information, we can treat the event announcement date as the event date, and the first trade day after the event announcement as the stock trading date.

\section{Model Description}

When the event was identified and the event period was determined, event study is used to calculate and to test market reaction of the behavior, which can examine the event whether content decision is usefulness information (Huang Xinjian and Yue Qiaoying, (2010))[11]. At first, we utilize the pre-event period data to estimate the expected returns before and after the event, and obtain abnormal returns by using the way the real returns minus the expected returns, then use statistical test methods to test whether to reject the null hypothesis. In this paper, we use stock returns as a measure of executive increased shareholding event market wealth effect indicators. The CSI 300 Index is chosen as the market base of comparison, which can represent the overall market performance.

The study period of executives increasing shareholding event with effect on stock price was divided into three windows, which include pre-event estimation period, event period and post-observation period. To executives increased shareholding event announcement date for the origin of coordinates, we select period in $[-150,-31]$ for pre-event estimation period, -150 for 150 trading days before the event announcement, where is a total of 119 trading day used to estimate the normal returns. The period for event period is $[-30,60]$, which with a total of 90 trading day is used to estimate the abnormal returns when the executives increasing shareholdings event happen. Here we will use the market model approach to estimate the expected stock returns (Yang Yang, Li Wei and Wei Xianhua (2014)) [12], and test whether the hypothesis is established.

Firstly, during the pre-event estimation period $[-150,60], P_{i t}$ is the price of the ith stock in the th day, we calculate the normal returns $R_{i t}$ by using the data $P_{i t}$ and $P_{i(t-1)}$ as follow:

$$
R_{i t}=\frac{P_{i t}-P_{i(t-1)}}{P_{i(t-1)}}
$$

In the case of the Capital Assets Price Model (CAPM) is established, the CAPM is used to calculate the expected returns $R_{i t}^{*}$ of the ith stock in the th day. In the pre-event estimation period we need to obtain the price volatility relationship between the stocks with the CSI 300 Index. $R_{m t}$ is the CSI 300 Index real returns in the th day during pre-event estimation period[-150, -31]. $\beta_{i}$ is the regression coefficient for ith stock real returns. $\varepsilon_{i}$ represent the regression residuals.

$$
R_{i t}=\alpha_{i}+\beta_{i} R_{m t}+\varepsilon_{i}
$$

We can use the least square method to estimated coefficients in the above formula. After the $\alpha_{i}$ and $\beta_{i}$ are solved from the model, if they stay stable in the pre-event estimation period. And then we can calculate the expected returns $R_{i t}^{*}$ of the ith stock in the event period [-30, 60] as follow:

$$
R_{i t}^{*}=\hat{\alpha}_{i}+\hat{\beta}_{i} R_{m t}
$$

Then we need to calculate the abnormal returns of the ith stock in the th day during the event period $[-30,60] A R_{i t}$ as follow: $R_{i t}$ is from equation (1), $R_{i t}^{*}$ is from Eq.3.

$$
A R_{i t}=R_{i t}-R_{i t}^{*}
$$

Then calculate the average abnormal returns of all the stock samples (the simple size is $n$ ) in the th day during the event period $A A R_{t}$ as follow:

$$
A A R_{t}=\frac{1}{n} \sum_{i=1}^{n} A R_{i t}
$$


At last, the cumulative abnormal returns during the event period can be calculated as follow:

$$
C A R_{t}=\sum_{i=1}^{t} A A R_{t}
$$

\section{Variables definition and Model}

We take the total assets net profit margin, dividend payout ratio, and operating income per share as the evaluation for companies performance levels and ability to grow. The PB indicators represent company's valuation, and a low PB represents that the value of the companies is undervalued. Information content before the event was represented by the average turnover ten days and cumulative abnormal returns five days before the event announcement date. The ownership concentration and the market capitalization is used for company inherent properties research.

Table 1 Variable Description

\begin{tabular}{|l|l|l|}
\hline Variable name & Symbol & \multicolumn{1}{c|}{ Variable Description } \\
\hline $\begin{array}{l}\text { Cumulative abnormal returns } \\
(\%)\end{array}$ & $\mathrm{CAR}_{\mathrm{i}[1,30]}$ & $\begin{array}{l}\text { Sum of abnormal returns during 30 trading days after the event } \\
\text { announcement date }\end{array}$ \\
\hline Market capitalization (RMB) & $\mathrm{Size}_{\mathrm{i}}$ & The market capitalization at the time of event announcement date \\
\hline Ownership Concentration(\%) & $\mathrm{Control}_{\mathrm{i}}$ & The largest shareholder stake proportion \\
\hline Dividend Payout Ratio (\%) & $\mathrm{Dpr}_{\mathrm{i}}$ & From the company's annual report published in the recent year \\
\hline Price-book ratio (\%) & $\mathrm{PB}_{\mathrm{i}}$ & The PB at the time of event announcement date \\
\hline Total assets net profit margin (\%) & $\mathrm{ROA}_{\mathrm{i}}$ & From the company's annual report published in the recent year \\
\hline $\begin{array}{l}\text { Operating income per } \\
\text { share(RMB per share) }\end{array}$ & $\mathrm{Share}_{\mathrm{i}}$ & Calculated by the latest data on equity and annual report data published \\
\hline $\begin{array}{l}\text { Average turnover ten days } \\
\text { before the event (\%) }\end{array}$ & $\mathrm{TUN}_{\mathrm{i}}$ & $\begin{array}{l}\text { Calculated by the data of turnover ten days before the event } \\
\text { announcement date }\end{array}$ \\
\hline $\begin{array}{l}\text { Cumulative abnormal returns } \\
\text { five days before the event }(\%)\end{array}$ & $\mathrm{CAR}_{\mathrm{i}[-5,0]}$ & $\begin{array}{l}\text { Calculated by the data of abnormal returns five days before the event } \\
\text { announcement date, and the benchmark for abnormal returns is the CSI } \\
300 \text { Component Index }\end{array}$ \\
\hline
\end{tabular}

We take the multiple regression analysis method to build the model as Eq.7, when the listed company executives increase shareholding events happen, we find out the key factors which has a significant effect on the market. And $\varepsilon_{i}$ is the residual, which is used for explain the unexplainable factors. Finally, $\gamma_{i}$ is the regression coefficient.

$$
\text { CAR }_{i[1,30]}=\alpha+\gamma_{1} \text { Size }_{i}+\gamma_{2} \text { Control }_{i}+\gamma_{3} \text { Dpr }_{i}+\gamma_{4} P B_{i}+\gamma_{5} \text { ROA }_{i}+\ldots+\gamma_{6} \text { Share }_{i}+\gamma_{7} T N_{i}+\gamma_{8} \text { CAR }_{i[-5,0]}+\varepsilon_{i}
$$

\section{Empirical Analysis}

\section{Statistical results of the market reaction}

The obvious market performance during the pre-event period is used to test whether event information is leak, or the stock appears the advance reaction. The stock performance during 60 trading days after the executives increase shareholding events date, which is used for test the dynamic change of event effects. Picture 1 shows the average abnormal returns' every trading day changes during the event period of 2735 samples from January 1, 2007 to the December 31, 2013.

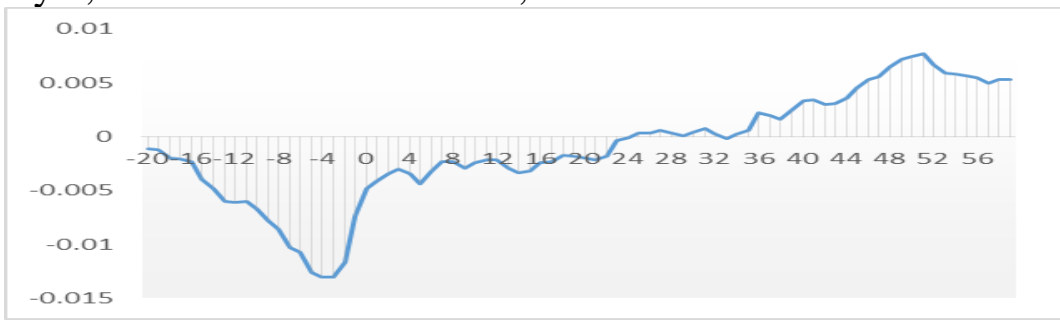

Figure 1 Average abnormal returns' every trading day changes during the event period 
Figure 1 shows the trend of average abnormal returns which price volatility obviously from the 20 trading days before the event date to the 60 trading days after the event date. We can observe the basic trend of abnormal returns, before the event announcement date, most of the stocks goes down. We can illustrate that executives have a precise timing ability in the increasing shareholding events. The stock shows significant positive abnormal returns after the event announcement, which stays a continuous growth trend for 50 trading days. So we confirm that executives increasing shareholding events have some information content.

Table 2 Executives increase shareholding events' CAR performance in the different window

\begin{tabular}{|c|c|c|c|c|c|c|c|c|c|}
\hline window & {$[-30,-1]$} & {$[-20,-1]$} & {$[-10,-1]$} & {$[-5,-1]$} & 0 & {$[1,5]$} & {$[1,10]$} & {$[1,20]$} & {$[1,30]$} \\
\hline$C A R_{t}$ & -0.001 & -0.0028 & 0.0038 & $(0.0078)^{* *}$ & $(0.0023)^{* *}$ & $(0.0067)^{* *}$ & $(0.016)^{* *}$ & $(0.031)^{* *}$ & $(0.041)^{* *}$ \\
\hline
\end{tabular}

Remark: ** and * represent at the $5 \%$ and $10 \%$ significance level is significantly non-zero.

On the other hand, we can learn something from the table 2 . The stock price volatility appears significantly larger in five trading days before the executives increase shareholding events announcement date, and there are negative abnormal returns in the 30 trading days and 20 trading days before the events announcement date, but there is a significant positive abnormal returns near the events announcement date. We take hypothesis test to market reaction results after the events announcement date. Cumulative abnormal returns of 20 trading days and 10 trading days before the events announcement date are statistically significant (non-zero). We can confirm that the market generate positive wealth effect after the executives increasing shareholding events. So the first hypothesis is confirmed.

\section{Correlation analysis between variables}

Pearson correlation test. From the Pearson correlation test result. We can learn that the correlation between most variables are very small. The largest correlation is between ownership concentration and ten days average turnover before the event announcement, which correlation coefficient is 0.385 . However, there is not significant correlation between the two properties. Therefore, we believe that most of the relevance are acceptable. And other variables data can pass the significant test. Since a small number of variables in the correlation is from 0.1 to 0.3 , we also make the principal component analysis by SPSS Statistics 20 before modeling. KMO value between test variables is only 0.503 , which is not suitable enough to do the principal component analysis. In the multiple regression analysis model, variance inflation factor VIF value is nearby 1 , which is far less than 10 . So there is not obvious multi-collinearity between these factors.

Regression coefficients and hypothesis verification. Table 3 lists the model results. The regression coefficient of each variable in the eq.7, where ownership concentration ( Control $_{i}$ ) and the market capitalization $\left(\right.$ Size $_{i}$ ) have a negative correlation with the cumulative abnormal returns after the event announcement. We can indicate that the less concentrated ownership and the lower probability of large shareholders against the interests of minority shareholders the companies appears, the more obvious market reaction can be got after the event announcement. It also shows that outside investors are more willing to hold shares of the listed companies with a less concentrated ownership. The companies with a smaller market capitalization and a better liquidity in the capital markets, cost investors in the lower cost to buy the shares. The positive results show that the companies the minority shareholders' interests being protected will get more abnormal returns after the event announcement. So the second hypothesis is confirmed.

The average turnover rate within ten days $\left(T U N_{i}\right)$ and five days cumulative abnormal returns before the event announcement $\left(C A R_{i[-5,0]}\right)$ represent the information content in the pre-event period. In the model result they have a negatively correlated with the cumulative abnormal returns after the event announcement. The market reaction is less obvious before the event announcement indicates that the less information leaked in the pre-event period. Under a certain amount of the information content of individual event, there is more cumulative abnormal returns after the event announcement. So the third hypothesis is confirmed.

The price-book ratio $\left(P B_{i}\right)$ is significantly negative correlation with the cumulative abnormal returns after the event announcement, which indicates that executives make full use of the advantages of the 
valuation judgment and insider information. The more undervalued market value is, the more obvious after executives increasing shareholdings announcement the market reaction is. Executives are good at choosing a good market timing to pass out information, boost the companies' stock price when the value of the companies is undervalued and the company stock price in a poor performance for a while in order to achieve management objectives as previously agreed. So the forth hypothesis is confirmed.

The total returns on assets $\left(R O A_{i}\right)$ and operating income per share ( Share $\left._{i}\right)$ have positive correlation with the cumulative abnormal returns after the event announcement, which indicates that executives prefer to use information advantage of the company history and the future development. In addition, executives would not take a big risk to hold a stock with the company's poor performance, not to mention increasing shareholding a stock. This conclusion is further illustrated that executives have the information advantage to choose the good timing of increasing shareholdings and boost investor confidence, in order to get abnormal returns. So the last hypothesis is confirmed.

Table 3 Regression coefficients

\begin{tabular}{|c|c|c|c|c|c|c|c|c|c|c|}
\hline \multirow[b]{2}{*}{ Model } & \multicolumn{2}{|c|}{$\begin{array}{c}\text { Non-standardized } \\
\text { coefficients }\end{array}$} & \multirow{2}{*}{$\begin{array}{c}\text { Standardized } \\
\text { coefficients } \\
\text { Trial } \\
\text { version } \\
\end{array}$} & \multirow[b]{2}{*}{$\mathrm{t}$} & \multirow[b]{2}{*}{ Sig. } & \multicolumn{3}{|c|}{ Correlation } & \multicolumn{2}{|c|}{ Co-linearity statistics } \\
\hline & B & $\begin{array}{r}\text { Std } \\
\text { error }\end{array}$ & & & & $\begin{array}{l}\text { Zero-o } \\
\text { rder }\end{array}$ & Bias & $\begin{array}{l}\text { Sec- } \\
\text { tion }\end{array}$ & Tolerance & VIF \\
\hline Constant & 8.210 & .864 & & 9.508 & .000 & & & & & \\
\hline $\mathrm{PB}_{\mathrm{i}}$ & -.507 & .119 & -.089 & -4.246 & .000 & -.089 & -.087 & -.086 & .933 & 1.072 \\
\hline $\mathrm{ROA}_{\mathrm{i}}$ & .323 & .095 & .070 & 3.409 & .001 & .070 & .070 & .069 & .957 & 1.045 \\
\hline $\mathrm{TUN}_{\mathrm{i}}$ & -.388 & .203 & -.044 & -1.911 & .046 & -.026 & -.039 & -.039 & .773 & 1.293 \\
\hline $\mathrm{CAR}_{\mathrm{i}-50]}$ & -.121 & .036 & -.071 & -3.384 & .001 & -.085 & -.069 & -.068 & .937 & 1.067 \\
\hline Control $_{i}$ & -.083 & .017 & -.110 & -4.920 & .000 & -.100 & -.101 & -.099 & .819 & 1.221 \\
\hline Size $_{i}$ & $-7.728 \mathrm{E}-10$ & .000 & -.046 & -2.246 & .025 & -.053 & -.046 & -.045 & .955 & 1.047 \\
\hline $\mathrm{Dpr}_{\mathrm{i}}$ & -.020 & .013 & -.032 & -1.567 & .047 & -.054 & -.032 & -.032 & .969 & 1.032 \\
\hline Share $_{i}$ & .161 & .067 & .049 & 2.388 & .017 & .046 & .049 & .048 & .973 & 1.028 \\
\hline
\end{tabular}

a. The dependent variable: $C A R_{i[1,30]}$

Model Performance Verification. To test the extrapolation performance of the model, we use the data from January 1, 2014 to September 25, 2014 for verification. According to the cumulative abnormal returns after the event announcement date, then we sort the above samples by the cumulative abnormal returns, then the top 50 percent of the sample as a high score group, and the rest as a low score group. Then we using statistical tests (T-test) to test whether there is a significant difference cumulative abnormal returns after the event announcement date between high and low score group. In order to test the accuracy of model, we compare the cumulative abnormal returns to the actual cumulative abnormal returns both the high score group and the low score group obtained by the training model.

Table 4 Descriptive statistics

\begin{tabular}{llllllllr}
\hline & $\mathrm{N}$ & Range & Min & Max & Sum & Mean & STD & VAR \\
\hline High & 132 & 1.096050 & -.241891 & .854159 & 7.923125 & .06002367 & .139690037 & .020 \\
Low & 132 & .767572 & -.356455 & .411117 & 6.087400 & .04611667 & .128227669 & .016 \\
\hline
\end{tabular}

As the results shows in table 4 , we find that high score group is obvious greater than the low score group no matter in the maximum and minimum indicator. And the sum and mean indicator of high score group is greater than the low score group, which shows that high score group's expected abnormal returns is significant greater than the low one.

Table 5 Single sample test

\begin{tabular}{|c|c|c|c|c|c|c|}
\hline \multirow[b]{3}{*}{$\begin{array}{l}\text { difference between two } \\
\text { groups }\end{array}$} & \multicolumn{6}{|c|}{$\mathrm{u}=0$} \\
\hline & $\mathrm{T}$ & $\overline{D F}$ & $\begin{array}{c}\text { Sig. } \\
\text { (double) }\end{array}$ & $\mathrm{md}$ & $\begin{array}{c}\text { DIF }(95 \%) \mathrm{C} \\
\text { down }\end{array}$ & $\begin{array}{l}\text { nce Intervals } \\
\text { up }\end{array}$ \\
\hline & .807 & 131 & .421 & .0139070076 & -.020175306 & .047989321 \\
\hline
\end{tabular}

Shown in the above table is the statistical test for the difference between the two groups. Test results in Table 5 shows that the samples do not pass the statistical test and reject the null hypothesis. So we can 
accept the alternative hypothesis, which the high score group get a significant greater abnormal returns than the low score group. The results show that the model extrapolation is valid.

\section{Summary}

In this paper we take the executives increasing shareholdings event which taking place in Shanghai and Shenzhen listed companies as study samples, and use the event study as the analytical method. The results show that the executives significantly stronger than the outside investor in predicting the company's performance and valuation capability. There are four favorable factors significantly affected the market reaction of the executives increasing shareholdings event. If the listed companies have such characteristics like lower valuation of companies, smaller market capitalization, lower ownership concentration, and lower stock prices volatility before the event, theirs stock price volatility are susceptible to executives behaviors. When the companies show more undervalued and considerable corporate earnings forecasts, outside investors more prefer to increase the shares. And the market reaction is more obvious. In the case of the information about the event leaks less in the pre-event period, the larger the market reaction can be got after the event. It can be explained that before the event announcement the stock market reactions were subjected to severe respected, investor buy the shares in relatively high cost. In addition, we verify the performance of model which can use as investment reference. And the company's valuation and stock prices in the pre-event period are closely related to event market reaction. In this paper we provide relevant evidence that most of the executives have good market timing and insider information superiority in increasing shareholdings, which shows the behaviors have some information content and there are a certain effectiveness asset allocation from china capital market.

\section{References}

[1] J. Dennert, Insider Trading, New Jersey: Blackwell Publishing Press, 1991.

[2] W. Aussenegg, and Ranzi, 2008. Corporate Insider Trading and the Short-Run Price Impact of Private Information in Continental Europe. SSRN Working paper.

[3] Yang Yang. Senior manager's shareholding increase in listed companies: studies for the motivation and the market effect. Southwestern University of Finance and Economics.March in 2013.

[4] Huang Jiacheng and Wang Zebin. Executive changes in the process of study on the earnings management behavior. Friends of Accounting, 2013(9)pp. 58-63.

[5] S. Friederich, A. Gregory, J. Matatko and I. Tonks, 2002. Short-run Returns around the Trades of Corporate Insiders on the London Stock Exchange. European Financial Management, Vol.8, pp 7-30.

[6] S. Claessens, S. Djankov, and H.P. Lang, 2000. The Separation of Ownership and Control in East Asian Corporations. Journal of Financial Economics, Vol.58, pp. 81-112.

[7] Zhu Tufen, Li Zhiwen and Chen Chao. The Market Timing and Reaction of Large Shareholders' Sales in China. Journal of Zhejiang University, 2011(5)pp. 140-146.

[8] Fang Tianliang. Major shareholders to increase its stake and empirical study of short-term fluctuations in the companies' share price. Statistics and Decision 2010(12)pp. 140-142.

[9]J.Lakonishok and I.Lee, Are Insider Trades Informative? Review of Financial Studies, Vol.14, No.1 (2001), pp. 79-111.

[10] Yu Haiyun and Wang Zebin. Financial performance and major shareholders holding ability with large holdings of shareholders empirical evidence from China's Shanghai and Shenzhen stock market holdings of shareholders. Communication of Finance and Accounting,2010(33)pp. 72-74.

[11]Huang Xinjian and Yue Qiaoying. Study on information content placement announcements of listed companies in China. Journal of Chongqing University. Seventeenth in 2011 pp. 51-53. 